\title{
An Evaluation of an Integrated Disaster Management and an Emergency Assembly Area: The Case of Kadıköy, Istanbul
}

\author{
Yasin Bektaş ${ }^{1 \odot}$, Adem Sakarya ${ }^{2} \odot$ \\ 1 Assist. Prof. Dr., Department of City and Regional Planning, Faculty of Architecture, Erciyes University, Kayseri, Turkey, \\ (Principal contact for editorial correspondence), Email: yasinbektas@erciyes.edu.tr \\ 2 Dr., Department of City and Regional Planning, Faculty of Architecture, Yildiz Technical University, Istanbul, Turkey. Email: \\ asakarya@yildiz.edu.tr
}

\section{Abstract Purpose}

The present study aims to analyze the accessibility and adequacy of the emergency assembly areas (EAAs) in Kadıköy which has the highest ratio of at-risk buildings in Istanbul. Design/Methodology/Approach

In this study, accessibility and adequacy of the EAAs are analyzed. To analyze the accessibility network analysis carried out within a geographic information system (GIS) program is used. Through an accessibility analysis, the ratio of the population that resides within $500 \mathrm{~m}$ walking distance of each EEA was ascertained. Furthermore, an adequacy analysis was carried out to measure the size of each emergency assembly area, and its adequacy for the population within its catchment area was analyzed. In addition, an accessibility and adequacy analysis were made of the social infrastructure facilities that have been defined as second-level emergency assembly areas.

\section{Findings}

According to the research findings, 57 percent of the current population of the district resides within $500 \mathrm{~m}$ of one or more of Kadıköy's 73 EEAs. It was found also that the emergency assembly areas accessible by three-quarters of the population within $500 \mathrm{~m}$ could be considered inadequate. Based on these findings, it was concluded that emergency assembly areas should be of adequate size, away from disaster risks and accessible to all residents, and that the standards for the open and closed areas within the emergency assembly areas should be defined in legislation and included as mandatory in future plans.

\section{Research Limitations/Implications}

The research was limited to Kadıköy which has the highest ratio of at-risk buildings in Istanbul.

\section{Originality/Value}

When evaluated alongside relevant studies regarding EAAs, the present study can be said to contribute to literature in its analysis of both the accessibility and adequacy of the existing EAAs and secondary assembly areas, taking a holistic approach, the study makes use of a network analysis method in the GIS program to identify the number of people living in each residential structure within the Kadıköy district. In addition, the study seeks to contribute further to literature by measuring the accessibility of social and technical infrastructure within the city planning discipline through a network analysis.

Keywords: Disaster risk, emergency assembly area, integrated disaster management, network analysis, urban planning 


\section{INTRODUCTION}

Turkey's urban areas are home to some 93 percent of the country's population (TUIK, 2019), and the risks that have come to be associated with urban areas related to disasters have had a significant effect the current situation and the urban development of cities. In the first decades of the 2000s, the risks associated with such natural phenomena as earthquakes, floods, floods, tsunamis, storms, hail, torrential rain, extreme temperatures and drought that were affecting Turkey's cities started to be discussed. The 1999 Marmara-Gölcük earthquake, the 2011 Van earthquake, the 2020 Elazığ-Malatya earthquake, the 2009 Ayamama flood, the 2016 Mersin flood, the 2018 Ankara Mamak flood and the 2019 Düzce flood are just a few of the various disasters witnessed in our country within the last two decades. Similar natural events affecting cities, how it was prepared to settle in Turkey against a variety of disasters and the discipline of disaster management have risen to the top of the agenda in the discipline of urban planning.

"Disaster management" involves analysis, planning, decision-making and evaluation activities and the organization of available resources with the objectives of preparedness, risk reduction, intervention and protection against various hazards (Kadığlu, 2008, p.12). Disaster management is thus an integrated approach that includes not only disaster response and post-disaster recovery processes, but also predisaster preparedness and damage limitation activities. In this context, it is of vital importance to establish emergency assembly areas (EAA), which is the first stage area prior to moving on to the evacuation area ${ }^{1}$ and to establish temporary shelters in the wake of a disaster. EAAs, serve various functions in disaster management, as muster points, evacuation areas, emergency aid centers and temporary accommodation areas. For this purpose, Spaces that usually function as parks, public squares, sports arenas and religious and educational facilities can be refunctioned as emergency assembly areas (UDSEP2; KENTGES3). The size, spatial distribution, usability, accessibility and connections to emergency transportation routes of EAAs earmarked for use in the event of a disaster are of vital importance. The previous earthquakes in İstanbul, which is home to approximately one-fifth of the country's population, and the large earthquake that is predicted to hit Marmara ${ }^{4}$ have led to an increase in the discussions of the need for EAAs that was first identified after the Marmara earthquake in 1999. However, these discussions have mostly centered on the number and size of these areas, and whether or not they are zoned for construction. For an integrated disaster management approach, however, the accessibility of these areas and their adequacy for the existing population should be discussed as a priority within the planning discipline. Researching the adequacy and accessibility of the EAAs for compliance with the planning criteria is the main research question of the study. The present study aims to determine the level of accessibility and adequacy of the
1 Evacuation areas; It refers to the wider areas where people will be evacuated safely from the disaster area, close to transportation routes and larger than the emergency assembly areas.

2 National Earthquake Strategy and Action Plan

3 Urban Development Strategy-Integrated Urban Development Strategy and Action Plan (2010-2023)

4 It is expected with a probability of $62 \%$ that an earthquake with a magnitude greater than 7 will occur within the next 10 years in the Marmara region (İstanbul Urban Transformation Master Plan Analysis data, 2016). 
5 Kadıköy District also according to JICA Disaster Prevention / Mitigation Basic Plan (2002); this is among the İstanbul districts where the ratio of parks and open spaces to people, required for pre-evacuation, is the least.

6 Accessed from: https://www.metro.tokyo.lg. jp/english/guide/bosai/inde x.html.

7 Religious facility area, education facility area, sports facility area, health facility area etc.
An Evaluation of an Integrated Disaster Management and Emergency Assembly Area: The Case of Kadıköy, Istanbul

established EAAs based on an analysis of Kadıköy, ${ }^{5}$ as the İstanbul district with the largest number of at-risk buildings.

Most of the research on disaster preparedness in the international literature are directed towards temporary shelter areas (Kar and Hodgson, 2008, Li et al. 2012, Chen et al., 2017). In addition, there are some crucial studies regarding emergency assembly/evacuation areas in the international literature. One of the most crucial of these is the "Disaster Preparedness Tokyo" report (TMG, 2015). The Tokyo Metropolitan Government has published a "Disaster Preparedness Tokyo" to help people get prepared for various disasters. It contains easy to understand information on how people use evacuation places, temporary evacuation area and evacuation center during the disasters. This information also proactively prepares people in the event of an emergency (TMG, 20156). Furthermore; Tansley et al. (2015) evaluated the level of accessibility of the emergency service areas in Namibia and Haiti; and Ye et al. (2012) analyzed access to temporary shelter areas under different scenarios within the Lujiazui Street region in Shanghai. Wex et al. (2014) develops a corresponding decision support model that minimizes emergency response times.

As for national cases; there have been previous studies questioning the accessibility and adequacy of emergency assembly areas and evaluating their features from different perspectives. Aksoy et al. (2007) determined that the green areas in the Fatih district of İstanbul would be appropriate as muster points after examining the status of these areas before and after the Marmara earthquake. Çınar, Akgün and Maral (2018) made an analysis of the location and characteristics of the EAAs in the district of Karşlyaka in İzmir and compared the results with national and international standards; while Zengin Çelik et al. (2019) analyzed emergency assembly areas in different urban textures in the Narlıdere district of İzmir; Aman (2019) investigated the landscape infrastructure of the EAAs within the open and green areas of the Bağcllar district of İstanbul; Erdin et al. (2018) studied the EEAs within the İzmir province, analyzing their integration with the transportation network; and another such study was carried out by Buldurur and Kurucu (2015), who investigated emergency transportation connections in İstanbul. On the subject of accessibility, Erdem, Erdin and Özcan (2017) examined the accessibility of emergency assembly areas during disasters; while Zengin Çelik et al. (2017) evaluated the usability of EAAs. In their study, Unal and Uslu (2016) carried out a network analysis using a geographic information system (GIS) program in which they examined the accessibility of the temporary shelter areas in Adana. When evaluated alongside these previous studies, the present study can be said to contribute to literature in its analysis of both the accessibility and adequacy of the existing EAAs and secondary assembly areas, ${ }^{7}$ taking a holistic approach, the study makes use of a network analysis method in the GIS program to identify the number of people living in each residential structure within the Kadiköy district. After an analysis 
of the findings, the study identifies the regions that are most in need of intervention and improvement.

In addition, the study seeks to contribute further to literature by measuring the accessibility of social and technical infrastructure within the city planning discipline through a network analysis. In the scope of this study, the integrated approach to disaster management and the situation in Turkey were firstly investigated, after which the planning criteria related to emergency assembly areas were explained. Afterwards, the national laws and regulations related to EAAs were evaluated, and the responsibilities defined in city planning legislation were analyzed. In the Method section, the data set and the analysis method applied within the research were explained, and the findings related to the accessibility and adequacy of the EAAs in Kadıköy were presented. This section also presents the results of the analyses of the accessibility and adequacy of the social infrastructure (Çınar et al., 2018) in the locations defined as secondary assembly areas. Finally, the results are evaluated and suggestions are made related to disaster management and EAAs, primarily for the Kadıköy district.

\section{LITERATURE REVIEW}

\section{Integrated Disaster Management Approach and the Situation in Turkey}

Policies related to disasters underwent a substantial reworking toward the end of the 1990s. One of the most important goals of these changes was to address the post-disaster "dressing the wounds" activities that had previously shaped disaster policies, and involved the development of a disaster management approach that included policies aimed at the development of disaster preparation and risk reduction approaches after determining pre-disaster hazards and risks (Balamir, 2007). This new approach to disaster management aimed to reduce the long-term macro losses linked to disasters (Balamir, 2007). Reducing the negative effects of disasters on sustainable development has become one of the global targets (Okay, 2019). The economic losses linked to disaster risks exceed the dimensions of the country ${ }^{8}$. The increase in the economic losses attributable to disasters since 1981 has been greater than the increase in per capita income, ${ }^{9}$ and disasters are, without doubt, among the most significant problems preventing sustainable development (Kadıoglu, 2011; Okay, 2019). The International Decade for Natural Disaster Reduction (IDNDR) study of the United Nations was accepted as the starting point for new policies in an integrated approach to disaster management for the 1990-2000 period, after which, a new period of radical change in disaster management was embraced in line with the new strategies determined at the Yokohama Conference (1994) and with the "International Strategy for Disaster Reduction (ISDR)" established in 2000 in which these strategies were applied. The organization behind the ISDR hosted the Kobe Conference, and published a new declaration entitled the "Hyogo Action Framework"
8 Compiled from Murat Balamir's speech during the Gazi University City Talks in 2015.

9 Compiled from Murat Balamir's speech during the Gazi University City Talks in 2015. 
10 In our country, the August 17 and November 12 earthquakes of 1999 caused more than 17,600 deaths, and economic loss was calculated to be over $\$ 12$ Billion (Güler, 2008, p.40).

11 For example, the Disaster Mitigation Act enacted in the United States in 2000 (Disaster Mitigation Act) (Balamir, 2007).

12 Disaster management stages include risk reduction efforts and planning studies (Kadıoğlu, 2011).
Figure 1. Classical disaster management cycle (adapted from Kadıoğlu, 2011).

13 Regulation No. 1959 7269 on Measures and Assistance to Be Entered into Effect Regarding Disasters Affecting the Life of the General Public; The State of Emergency Law No. 2935, which came into force in 1983; the Zoning Law No. 3194, which came into force in 1985; the Regulation on Emergency Aid Organization and Planning Principles regarding Disasters numbered 88/12777 in 1988; the Regulation on Buildings to be Constructed in Disaster Areas in 1996; and the Regulation on Prime Ministry Crisis Management Center, numbered 96/8716 that entered into force in 1997 (Balta, 2013, p.70,71).
An Evaluation of an Integrated Disaster Management and Emergency Assembly Area: The Case of Kadıköy, Istanbul

(2005-2015) (Balamir, 2007, p.32). In the "Disaster Risk Reduction Global Assessment Report" published by the United Nations Office for Disaster Risk Reduction (UNISDR) in 2013, the damage to the global economy resulting from natural disasters was determined to be $\$ 2.5$ trillion in $2000^{10}$ (Kundak, 2014). Many countries have developed their own regulations and practices related to risk mitigation, especially since the Yokohama Conference ${ }^{11}$ (Balamir, 2007, p.32). Within the scope of these regulations and practices, the most important role of integrated disaster policies is identifying the multiple risks that may lead to loss of life, property and environment, and to minimizing potential losses in the wake of disasters by reducing these risks (Balamir, 2007; Kadıoglu, 2011; Tezer \& Türkoğlu, 2008). The main beneficiaries of the new international disaster policies can be summarized as "urban areas" (especially areas where population and infrastructure are concentrated) and "low-income groups", and "participation" processes, as common issues that should be observed. Accordingly, the concept of integrated disaster management ${ }^{12}$ (Figure 1) involves analysis, planning, decision making and evaluation processes, covering all segments of the society, and preparing for all kinds of hazards, reducing possible risks and losses, and steering the post-disaster response and recovery stages (Kadığğlu, 2008; Kadığlu, 2011; Tezer, 2001; Tezer et.al. 2015).

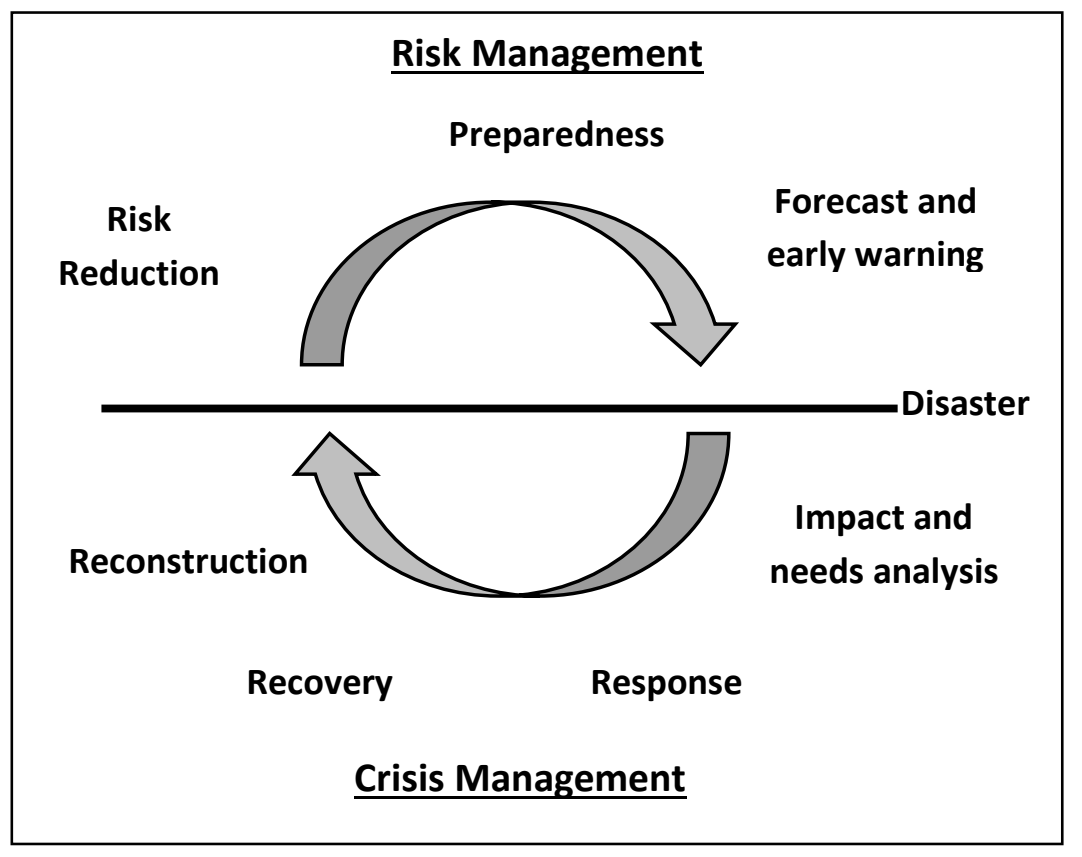

Radical changes were made to disaster-related policies after the 1999 Marmara earthquake in Turkey. An analysis of the legal and administrative situation ${ }^{13}$ prior to 1999 reveals that focus was mostly on the post-disaster response and recovery phase, and its spatial content, and that disaster risk reduction studies were few in number (Kadığlu, 2008; Kadığlu, 2011; Güler, 2008; Balamir, 2007; Okay, 2018; Tezer et al., 2015). Although studies were launched to determine 
potential hazards and risks and to take short-term protective measures and long-term preventive measures in Turkey's 1989 National Report as part of the "International Decade for Natural Disaster Impact Mitigation" drive of the United Nations (covering the years 1990-2000), these studies have not been successful due to lack of resources and problems in application (Güler, 2008, p.37). A new radical era in disaster management was embraced following the devastating 1999 Marmara earthquake in Turkey. As a result of the economic, social and environmental losses resulting from the earthquake, studies of disaster risk reduction and disaster resilience started to be given priority (Kundak, 2014; Okay, 2018). The "Disaster Prevention/Mitigation Basic Plan-2002" prepared by the Japan International Cooperation AgencyJICA for İstanbul in 2002, is one of the most important examples of newperiod studies, containing suggested approaches to damage estimation and risk reduction. Following this, through the Istanbul Earthquake Master Plan (2003) prepared by Boğaziçi University, Istanbul Technical University, Middle East Technical University and Yıldız Technical University, the different forms of urban risk (macroform risks, urban texture risks, land use risks, production loss risks, special risk areas, special building risks, risks arising out of dangerous use, emergency officer distribution risks, open areas risk analyses) were identified for the first time, and suggestions of how to reduce the risk of disasters were brought to the table with mitigation planning (Balamir, 2004; Balamir, 2011). The plan also introduced an "Action Plan" for high-risk areas where priority interventions were required, and provided details of the plan. The mitigation plan, containing detailed disaster risk reduction suggestions to raise the safety and resilience of Istanbul, still constitutes the basis for today's master plan studies, although it could not be applied (Istanbul Deprem Master Planı-IDMP, 2003). The Disaster and Emergency Management Presidency (DEMP), which was established in 2011 in accordance with the Law No. 5902 on the Disaster and Emergency Management Presidency, prepared a National Earthquake Strategy and Action Plan-2023 (NESAP) aimed at reducing the risks associated with disasters and facilitating the creation of resilient urban systems. The Turkey Disaster Response Plan (TDRP) and the Turkey Disaster Risk Reduction Plan (TDRRP) strategic documents, and the Provincial Disaster Risk Reduction Plan (PDRRR) are ongoing studies into the reduction of risks in the new era (Okay, 2019, p.55). In the recent development plans, the Ninth Development Plan proposes given the task and authority to prepare mitigation plan to local governance (Dokuzuncu Kalkınma Planı, 2006) and the conducting of micro-zoning studies in areas where there is a high risk of disaster, and the findings of these studies are to be taken into consideration in the zoning plan, as stated in the Tenth Development Plan, prioritizing the areas at the greatest risk of disaster (Onuncu Kalkınma Planı, 2013 ). In the Eleventh Development Plan, it was suggested that resilient urban systems and effective disaster management are also required to support 
13 T.C. İçişleri Bakanlığı, Afet ve Acil Durum Yönetimi Başkanlığı, Basın ve Halkla İlişkiler Müşavirliği. (2019). "Toplanma Alanını Öğren ki Canın Sağ Olsun-Basın Duyurusu". Accessed from: https://www.afad.gov.tr/top lanma-alanini-ogren-kicanin-sag-olsun

14 T.C. İçişleri Bakanlığı, Afet ve Acil Durum Yönetimi Başkanlığı, Basın ve Halkla İlişkiler Müşavirliği. (2019). “Toplanma Alanını Öğren ki Canın Sağ Olsun-Basın Duyurusu". Accessed from: https://www.afad.gov.tr/top lanma-alanini-ogren-kicanin-sag-olsun
An Evaluation of an Integrated Disaster Management and Emergency Assembly Area: The Case of Kadıköy, Istanbul

sustainable urban development; and the plan also proposed a development plan that takes into account disaster risks and hazards, along with provincial disaster risk reduction plans (On Birinci Kalkınma Planı, 2019). These developments in local governance can be assessed through an analysis of two laws. While planning studies related to natural disasters are proposed in the Metropolitan Municipality Law No. 5216; Municipality Law No. 5393 contains statements related to emergency planning, covering mostly the post-disaster period. The regulations on Spatial Planning and Construction, which came into force in 2014, details the measures to be taken when carrying out urban risk analyses or mitigation plan studies in urban regions where the risk of disasters is high., and to base them on the plans. Although the applications of the Law on the Transformation of Areas under Disaster Risk, numbered 6306, which entered into force in 2012, is aimed at risk reduction, its focus is on construction and ground risk. Master plan urban transformation studies have been carried out in certain provinces and districts, but have yet to be integrated into the spatial planning system and have not become nationally widespread.

In the developments mentioned above, although proposals for the disaster risk reduction plans are embedded within the legal and administrative framework, the many applications made in Turkey to date have been mostly directed at post-disaster response, while the participation dimension is observed to be lacking. Disaster management systems have become more widespread over the last decade, however a number of problems have been encountered, such as the lack of sustainability in the current preparedness and risk reduction stages, the inadequate participation of all stakeholders in the planning and decision-making processes, and the lack of effective studies into urban resilience (Okay, 2019). The planning of post-disaster evacuation areas is one of the most important components of disaster preparedness and risk reduction efforts, and can be categorized under three headings: 13 emergency assembly areas, evacuation areas and temporary shelter areas. Although emergency assembly areas were defined in our country after the 1999 Marmara earthquake, there are still significant deficiencies in their adequacy and accessibility, and so the criteria to be followed when planning such areas and their status in planning legislation should be examined as a priority.

\section{Planning Criteria for Emergency Assembly Areas}

EAAs, known also as local evacuation areas or pre-evacuation areas (JICA \& IBB, 2002), are defined as "safe areas to where people can relocate away from potential hazards" until temporary shelter centers after a disaster and emergency can be established. ${ }^{14}$ Such muster points play a crucial for those who survive the first shocks after a disaster, being places where they can locate their relatives, access communication, gain access to health information, satisfy their human needs, and transition to regional evacuation areas and temporary 
shelter areas in the future. Emergency assembly areas, referred to also as gold watches (Ergünay et al., 2008), play a crucial role in the first 72 hours following a disaster. The present study plays an important role when planning the accessibility and adequacy of these areas.

As stated in the previous section, while the strategic plans and action plans at a national level define targets and strategies aimed at creating more sustainable and resilient urban developments against disasters, in the planning regulations, the planning criteria of these areas are not clearly defined. According to the National Earthquake Strategy and Action Plan (2012-2023) prepared by the Disaster and Emergency Management Presidency (DEMP), and the Integrated Urban Development Strategy and Action Plan (2010-2023) prepared by the Ministry of Environment and Urbanization, transportation and evacuation corridors, emergency assembly and temporary shelter facilities etc. are to be provided to allow a rapid and effective response in the event of a disaster. To meet these objectives, the social infrastructure and their standards should be determined to be used after disasters according to the population and needs. In spatial planning, therefore, it is proposed to consider such functions as assembly points and transportation, health services, temporary shelter and logistics as a whole in the event of an emergency. However, it is stated that only under the title of implementation development plan in the regulations on Spatial Planning and Construction (Article 24, Clause 10) that the opinions of institutions and organizations related to assembly areas will be collected, and that analyses and researches will be carried out based on this data. That said, assembly points are not included in the plans of diverse scale, and the regulation on Spatial Planning and Construction includes only suggestions. The Planned Areas Zoning Regulation contains details of the use of national gardens as assembly points in the event of a disaster, although the planning criteria of such areas in terms of size, availability, links to emergency transportation routes, accessibility, adequacy, etc., have not been embraced in the regulation. Accordingly, determining the criteria to be followed in the planning of these areas is crucial for the enhancement of safety. Although no direct or precise planning criteria for emergency assembly areas has been produced in literature, there are diverse studies from which clues can be taken.

In the criteria proposed in the "Disaster Prevention Reduction Basic Plan" prepared for İstanbul by the Japan International Cooperation Agency (JICA \& IBB, 2002), as one of the main reference institutions in disaster risk reduction studies, the emergency assembly areas are evaluated at two scales, being "local evacuation areas" (emergency assembly areas) and "regional evacuation areas". Within this plan, emergency assembly areas have been determined at a neighborhood scale, with parks and open spaces as well as public lands and facilities in each neighborhood unit (primary school unit, 300-500 households/1500-2000 people) identified that can be easily accessed 
15 Very small parks and open spaces are not suggested an assembly area in order to be safe against building damage to the environment after the disaster (JICA \& IBB, 2002).

16https://www.cnnturk.com /video/turkiye/toplanmaalanlari-nasil-olmali, Date accessed: 22 January 2020

17 In the social facility areas that can be used as an emergency shelters in the study, the confined space standard per person has been accepted as $3.5-4.5 \mathrm{~m} 2$. (Çınar et al., 2018).

18 In the Disaster Regulation for Infrastructures No. 26435, issued in 2007, design and engineering calculations been made obligatory so that infrastructure facilities are resilient to natural disasters. In addition, the minimum requirements been made obligatory for the material selection, construction, operation, maintenance and repair of infrastructure facilities.
An Evaluation of an Integrated Disaster Management and Emergency Assembly Area: The Case of Kadıköy, Istanbul

by the public. Although there are public schools and mosques in all neighborhoods that are easily accessible, it has been determined that parks and open spaces of $2000 \mathrm{~m} 2$ (minimum $500 \mathrm{~m} 2$ ) $^{15}$ may be the most suitable locations as pre-evacuation areas, since schools and mosques are not seismically resilient. That said, disasters can occur in any weather conditions (snow, rain, storms, etc.), as emphasized in some studies, and human needs in winter conditions may not always be best met in open spaces. For this reason, sports arenas, and religious and educational facilities that have no nearby explosion risk (such as a gas station) and are earthquake resistant should be preferred as assembly points. ${ }^{16}$ As can be understood, there are two different approaches to the determination of appropriate emergency assembly areas. When these approaches are evaluated together, in the wake of a disaster, publicly-owned parks and green areas with no restricting elements within the structure or the surrounding areas should be treated as priority muster points (JICA \& IBB, 2002; Zengin Çelik et al. 2019). The presence of restrictive elements around such social facilities as schools, religious facilities, sports arenas (walls, fences, etc.) make them more appropriate as secondary assembly areas when evaluated in terms of earthquake resilience (Zengin Çelik et al. 2019; Çınar et al., 2018). On the other hand, some social facilities may offer emergency shelter in different climates, may have been made earthquake resistant, may better meet human needs and may have more usable features than parks and green areas. However, social facilities that have been made earthquake resilient and that can provide emergency shelter ${ }^{17}$ in different climatic conditions have more usable features than parks and green areas in terms of satisfying human needs.

Along with the quality of EAAs, another crucial criterion is the accessibility of such areas. Emergency assembly areas should be planned within a maximum walking distance of 500 meters of settlements, and should have a topography that permits easy and safe access to all segments of society, being within a 15-minute walk for also the elderly and children (Tarabanis \& Tsionus, 1999). Roads that are less than 7 meters wide are at high risk of closure (98\%) in the event of a disaster (JICA \& IBB, 2002), and so this should be taken into account when assigning such areas. Along with transportation, other technical infrastructures (natural gas, drinking water, sewerage network, rainwater, etc.) should be made resilient against various disasters. ${ }^{18}$

Another crucial criterion when determining the location of EAAs is topography, soil type, climatic features, and geological and geomorphological features. In the criteria defined by AFAD, while describing the determination of flatlands as assembly areas, it is suggested that the ideal slope value should be in the range of 2-4 percent in order to prevent rainwater from accumulating in the area (Çinar et al. 2018). Of the places to be determined as muster points, fault lines, stream beds, sand dunes, swamps and valley floors, and areas prone to landslides, floods, tsunamis, liquefaction and rockfalls etc. 
should be avoided as secondary hazards ${ }^{19}$ (Kadığlu, 2011). Assembly areas should also be planned considering the climatic conditions in diverse geographies. For example, taking into account the dominant wind direction to ensure air circulation in regions prone to high temperatures and humidity, and having adequate vegetation to provide shade are crucial design features that will increase the usability level of assembly areas when considered together with building densities and structure layouts. In addition, the possibility of unexpected/sudden climate changes should be taken into account, and assembly areas should be planned to include enclosed spaces that can protect people against such factors as excessive rainfall, extreme temperature, hail and storms within the first 72 hours following the disaster. As such, EAAs to be used in the event of a disaster, the emergency transportation routes, and the evacuation and temporary shelter areas should be designed to be least affected by urban risks. ${ }^{20}$

As can be understood from the above, there are many criteria to be taken into consideration when planning EAAs, although this study is focused on the accessibility and adequacy criteria, as prominent factors when planning social and technical infrastructure areas.

\section{DATA AND METHOD}

This study of integrated disaster management and emergency assembly areas (EAAs) takes the Kadıköy district of İstanbul, which has the highest ratio of at-risk buildings in the city, as the case study area. Within the scope of this examination the accessibility and adequacy of EAAs is analyzed, while related to these two analyses, the social infrastructure areas in Kadıköy are examined as secondary assembly areas.

For the purpose of this study, the EAAs in Kadıköy defined by the Disaster and Emergency Management Presidency (DEMP) in the egovernment portal, and the buildings (residential, social infrastructure or otherwise) and roads detailed on the base map of Kadıköy, provided by municipality, were used as data. The data was converted into a geographical information system (GIS) format to make it useable for the analyses.
19 T.C. İçişleri Bakanlığı, Afet ve Acil Durum Yönetimi Başkanlığı, Basın ve Halkla İlişkiler Müşavirliği. (2019). “Toplanma Alanını Öğren ki Canın Sağ Olsun-Basın Duyurusu". Accessed from: https://www.afad.gov.tr/top lanma-alanini-ogren-ki-

canin-sag-olsun

20 Macroform risks, urban texture risks, urban use risks, production loss risks, special risky area, special buildings risks, risks arising from dangerous uses, emergency officer distribution risks, open areas risk analysis (IDMP, 2003). 
An Evaluation of an Integrated Disaster Management and Emergency Assembly Area: The Case of Kadıköy, Istanbul

Table 1. Data and sources

\begin{tabular}{|c|c|}
\hline Data and usage & Source \\
\hline Emergency assembly areas & $\begin{array}{l}\text { Disaster and Emergency } \\
\text { Management Presidency }\end{array}$ \\
\hline $\begin{array}{l}\text { Residential buildings: In base map there is information } \\
\text { of functions for each building. To calculate the } \\
\text { population accessing to EAAs, residential buildings are } \\
\text { use. Buildings with other functions were excluded. }\end{array}$ & \multirow[t]{4}{*}{ Base map of Kadıköy } \\
\hline $\begin{array}{l}\text { Social infrastructure buildings (secondary assembly } \\
\text { areas): Schools, health units, mosques, indoor sports } \\
\text { areas and official buildings. }\end{array}$ & \\
\hline Roads: They are used for network analysis & \\
\hline $\begin{array}{l}\text { Roads narrow than } 7 \mathrm{~m} \text { : They were detected by } \\
\text { measuring cross sections of each road in base map. }\end{array}$ & \\
\hline
\end{tabular}

It is important for all inhabitants to be able to access an EAA within 500 $\mathrm{m}$, which is considered a walkable distance for them, including both children and the elderly, within 15 minutes (Tarabanis \& Tsionus, 1999) for efficient disaster management. In this respect, for the accessibility analysis, the ratio of the population with access to an EAA within $500 \mathrm{~m}$ was calculated. For this calculation, firstly, the total construction area of

21 There is no information about abandoned or vacant building, so it was assumed that all residential buildings are inhabited.

22 In this study, when the catchment areas of EAAs were calculated with a network analysis, it was found that $57 \%(261,125)$ of Kadıköy's total population $(458,638)$ had accessed to an EAA within $500 \mathrm{~m}$; but when calculated for a buffer zone, it was found that $80 \%$ $(365,760)$ of Kadıköy's total population had accessed to an EAA within $500 \mathrm{~m}$. It can be understood from these calculations that a buffer zone model that does not take road data into account will provide misleading results. the residential buildings in each neighborhood was divided by the population of the neighborhood in 2018 to provide the residential construction area per person for each neighborhood. Then, number of people living in each building ${ }^{21}$ was calculated by dividing construction area of each residential building by residential construction area per person in each neighborhood.

$\mathrm{N} a=\mathrm{C} a /(\mathrm{Cm} / \mathrm{Nm})$

$\mathrm{N} a$ : number of people living in "a" residential building

$\mathrm{C} a$ : total construction area of "a" residential building

$\mathrm{Cm}$ : total construction area of residential buildings in " $\mathrm{m}$ " neighborhood

$\mathrm{N} m$ : population of " $\mathrm{m}$ " neighborhood

To calculate the $500 \mathrm{~m}$ catchment area for each EAA for the accessibility analysis, a network analysis module in GIS was used. Instead of a buffer zone defining a catchment area based on distance as the crow flies, a network analysis is a spatial analysis method that gives more accurate results by using distances by road to define the catchment area (Tansley et al., 2015; Ye et al., 2012; Comber et al., 2008). ${ }^{22}$ The catchment area of all EAAs in Kadıköy and their populations were calculated through such a network analysis.

Additionally, an examination of road cross sections was made in the accessibility analysis, as roads narrower than $7 \mathrm{~m}$ have the high possibility of being blocked in the event of an earthquake (JICA \& IBB, 2002). The EAAs and their $500 \mathrm{~m}$ catchment areas were thus reexamined superposed with roads narrower than $7 \mathrm{~m}$. 
The EAA should be adequate for people living within $500 \mathrm{~m}$. Studies of disaster management and EAAs, and the criteria defined in these studies, state that EAAs must be at least $500 \mathrm{~m}^{2}$ if efficient disaster management is to be ensured, and with a minimum of $1.5 \mathrm{~m}^{2}$ gross area for each person (JICA \& IBB, 2002). Accordingly, an adequacy analysis was carried out in which the size of the EAA was divided by the number of people expected to access the area.

In these analyses it has been determined that not all inhabitants of Kadıköy have access to an EAA within 500 m, and so the accessibility and adequacy of the social infrastructures defined as secondary assembly areas (Zengin Çelik et al., 2017; Zengin Çelik et al., 2019) was analyzed.

Aside from being resistant to earthquakes, secondary assembly areas are of particular importance in the aftermath of those occurring in winter, providing shelter and such infrastructures as water, electricity and sewage. To analyze the accessibility of these areas, a $500 \mathrm{~m}$ catchment area for each building was determined with a network analysis, similar to the way in which the catchment areas of EAAs were determined. Then, to analyze the adequacy of these areas, the total construction area of these areas was divided by the population within the catchment area. In accordance with the standard for temporary shelter areas, at least $3.5 \mathrm{~m}^{2}$ is to be allotted per person (Ç.nar et al., 2018). Finally, the total construction area of the secondary assembly areas, the population accessing these areas within $500 \mathrm{~m}$ and the construction area per person were evaluated on a neighborhood scale.

\section{RESULTS}

It was determined from the Disaster and Emergency Management Presidency system and the Kadıöy city guide that there are 73 EAAs in Kadıköy. The city guide ${ }^{24}$ identifies 4 of these (coded as 7, 31, 47 and 67) as "main evacuation areas". At the same time, having the appropriate qualities to meet the requirements of EAAs, the main evacuation areas were all accepted as EAAs, and all are used normally as parks.

As to the spatial distribution of these 73 EAAs, the neighborhoods of Koşuyolu and Acibadem located in the northwest of the district; and Merdivenköy, Sahrayıcedit and 19 Mayıs, located in the northeast, draw particular attention. Furthermore, the Eğitim neighborhood has more EAAs than the others. On the other hand, in the neighborhoods like Rasimpaşa, Caferağa, Osmanağa, Hasanpaşa located in the historical center where there is agglomeration of commercial facilities; and in the neighborhoods in the east, like Erenköy, Suadiye and Bostancl, the number of EAAs is low (Figure 2).

${ }^{24}$ https://webgis.kadikoy.bel .tr/keos/

EAAs must be at least $500 \mathrm{~m}^{2}$ in size (JICA \& IBB, 2002), and 71 of the 73 EAAs in Kadıköy are larger than $500 \mathrm{~m}^{2}$. The EAA in Göztepe coded 30 and the EAA located in Feneryolu coded 46 are both between 400 and $500 \mathrm{~m}^{2}$. 
Figure 2. Spatial distributions of EEAs in Kadıköy

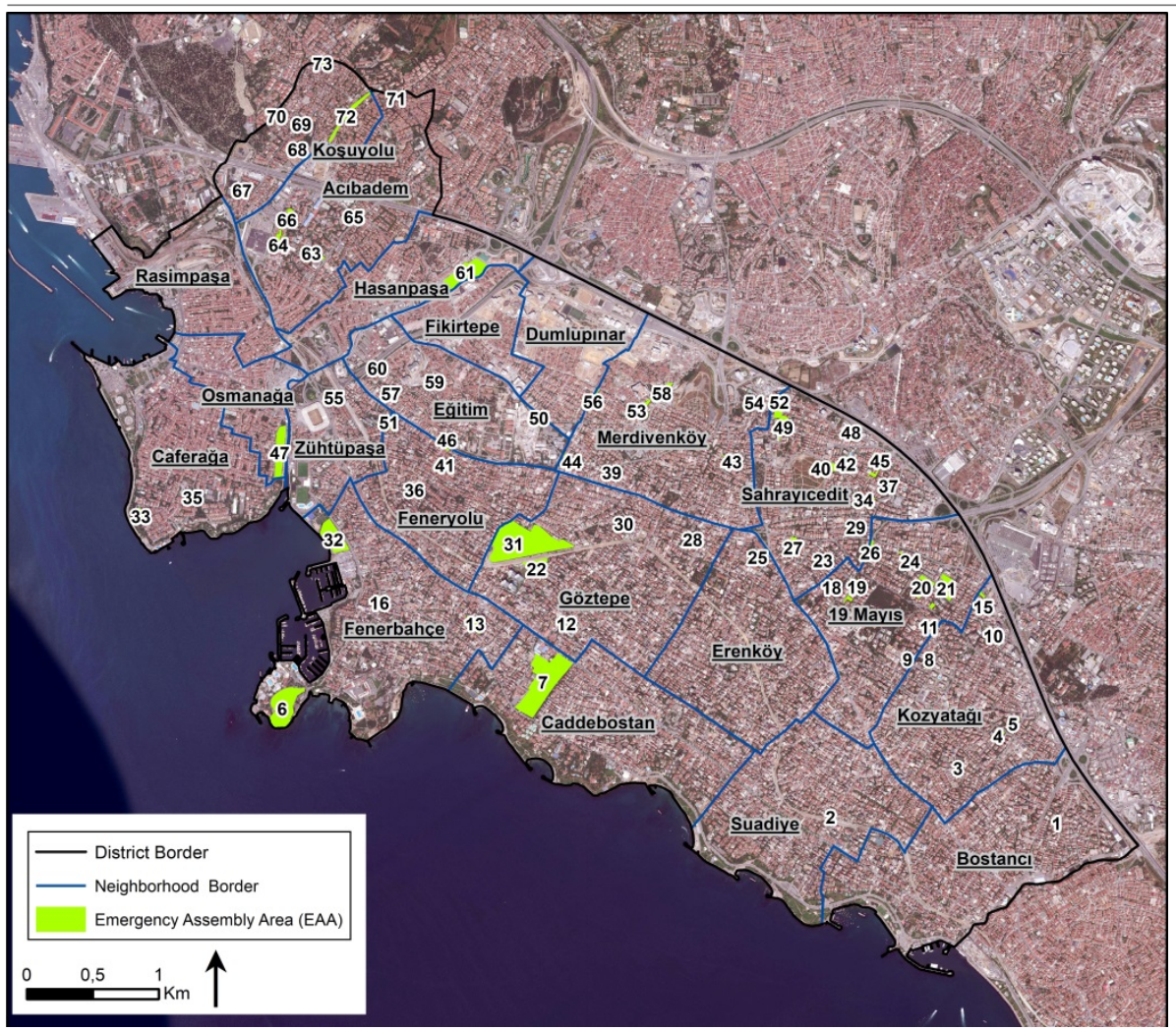

To determine the $500 \mathrm{~m}$ catchment area of each EAA and the population within the area, a network analysis on GIS was made.

The population of Kadıköy was recorded as 458,638 in 2018, and it was determined that 261,125 have access to an EAA within $500 \mathrm{~m}$, meaning 57 percent of the total population have access to an EAA within $500 \mathrm{~m}$. It was further found that the $500 \mathrm{~m}$ radius catchment areas cover 60 percent of the district.

As stated previously, planning EAAs on a neighborhood scale is crucial both for easy recognition and accessibility. At the neighborhood level, the ratio of the population with access to EAAs within $500 \mathrm{~m}$ to neighborhood population is greater than 80 percent in Merdivenköy, Eğitim and Koşuyolu, differentiating these neighborhoods from the others in the district. In the Rasimpaşa, Erenköy, Caddebostan, Bostancl, Osmanağa, Suadiye and Hasanpaşa neighborhoods, where there are fewer EAAs, but which are home to one-third of Kadıköy's population, this ratio is less than 40 percent. The most disadvantaged neighborhood is Rasimpaşa, where there are no EAAs, containing mostly commercial and service buildings, and where the ratio is less than 1 percent (Figure 3; Table 1). 


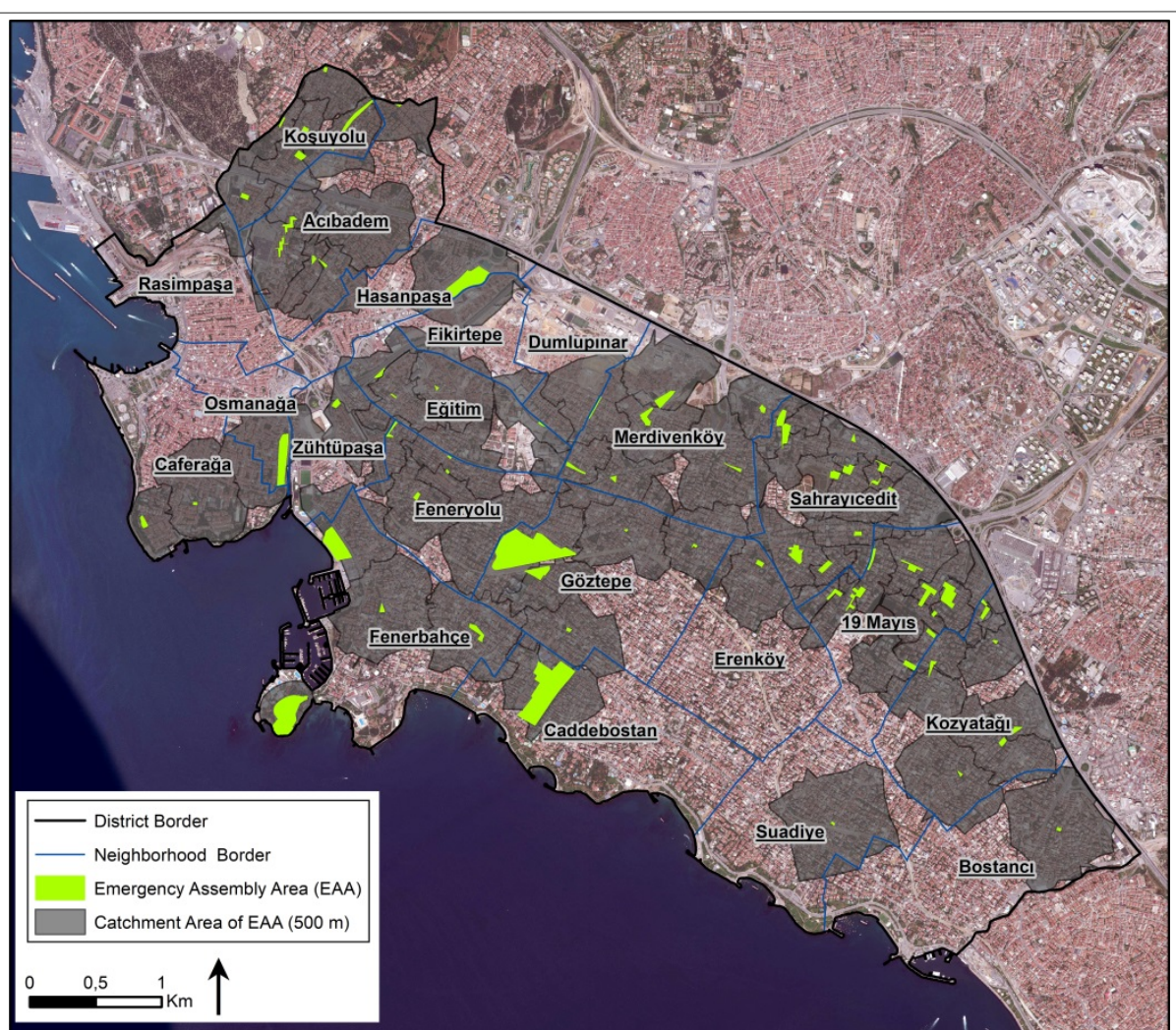

An important factor in efficient disaster management is the width of the roads providing access to EAAs, as roads that are likely to become blocked in the event of an earthquake (JICA \& IBB, 2002) can prevent access to EAAs. Accordingly, the presence of roads serving EAAs that are narrower than $7 \mathrm{~m}$ is examined by superposing in GIS.

As seen in Figure 4, access to the EEAs coded 33, 35 and 37 in the Caferağa and Osmanağa neighborhoods, the historical center of Kadıköy, is mostly via roads narrow than $7 \mathrm{~m}$, and so access to these EAAs can be considered problematic. All the other EAAs are served by roads that are both narrower than $7 \mathrm{~m}$ and wider roads.
Figure 3. Spatial distribution of $500 \mathrm{~m}$ catchment areas of EAAs in Kadıköy 
Figure 4. EAAs, catchment areas and roads narrower than 7 meter in Kadıköy
An Evaluation of an Integrated Disaster Management and Emergency Assembly Area: The Case of Kadıköy, Istanbul

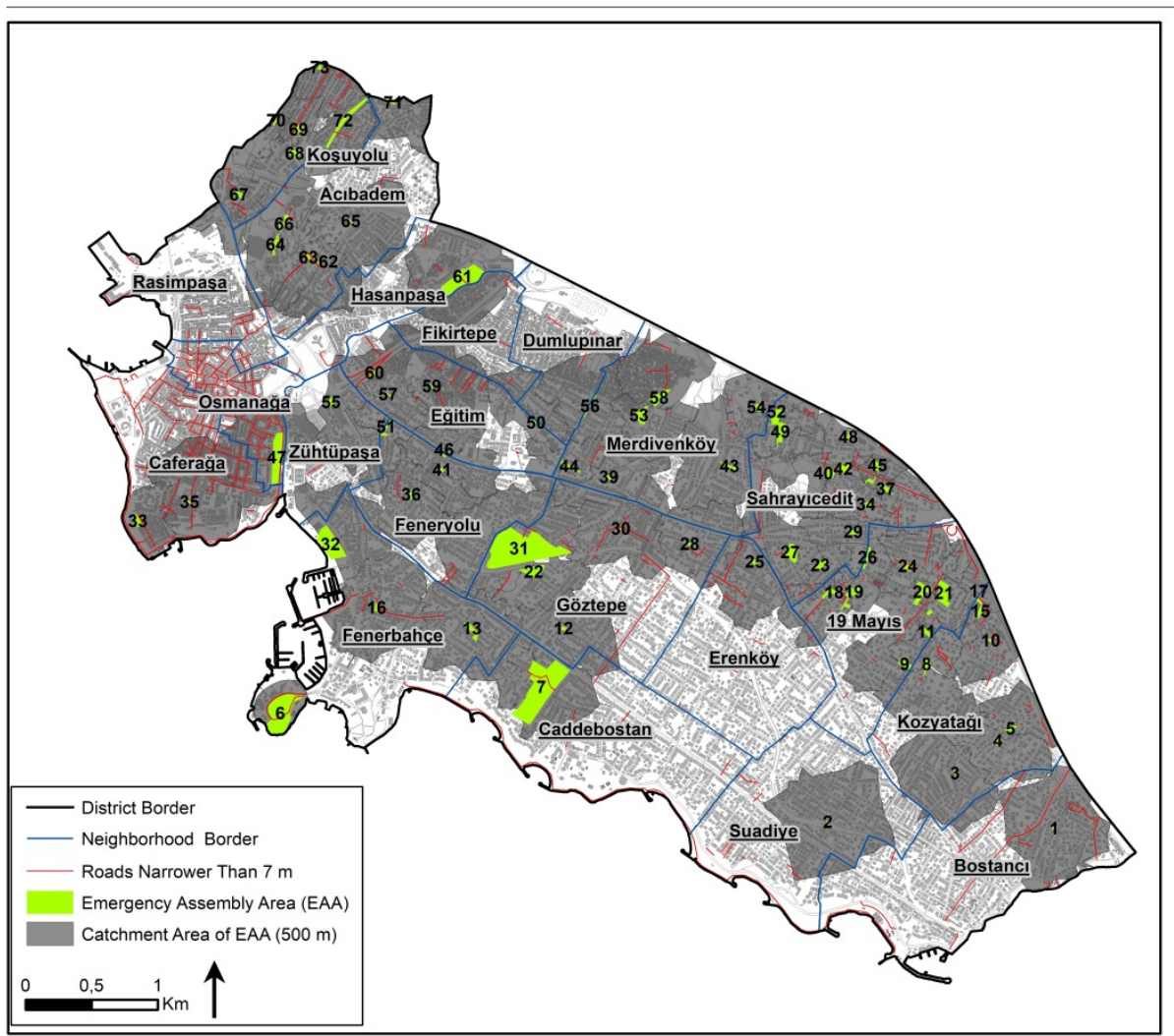

To determine if the EEAs provide adequate area for the population residing within $500 \mathrm{~m}$, a adequacy analysis was carried out.

As stated previously, 57 percent $(261,125)$ of the population of the district has access to an EAA within $500 \mathrm{~m}$, although only 27 percent of the population $(70,119)$ is within $500 \mathrm{~m}$ of an EAA of adequate area $(1.5$ $\mathrm{m}^{2}$ gross area per person), amounting to 15 percent of Kadıköy's population.

The EAAs that provide adequate area for the population within their catchment areas are densely located in the Koşyolu and Sahrayıcedit neighborhoods; where 70 percent and 40 percent of the population, respectively, have access to adequate EAAs within $500 \mathrm{~m}$. Additionally, the six largest EAAs, coded 31, 7, 6, 61, 32 and 47 (of which 31, 7, 61 and 47 are evacuation areas) in Kadıköy, provide adequate area for the population of their catchment area. These EAAs are located in the Hasanpaşa, Fikirtepe, Feneryolu, Zühtüpaşa and Osmanağa neighborhoods where the ratio of the population that can access adequate EAAs is greater than 20 percent. In contrast, this ratio is lower than 3 percent in the Bostancı, Suadiye, Dumlupınar, Eğitim, Rasimpaşa, Kozyatağı and Erenköy neighborhoods, which are home to 35 percent of the population of the district (Figure 5; Table 2). 


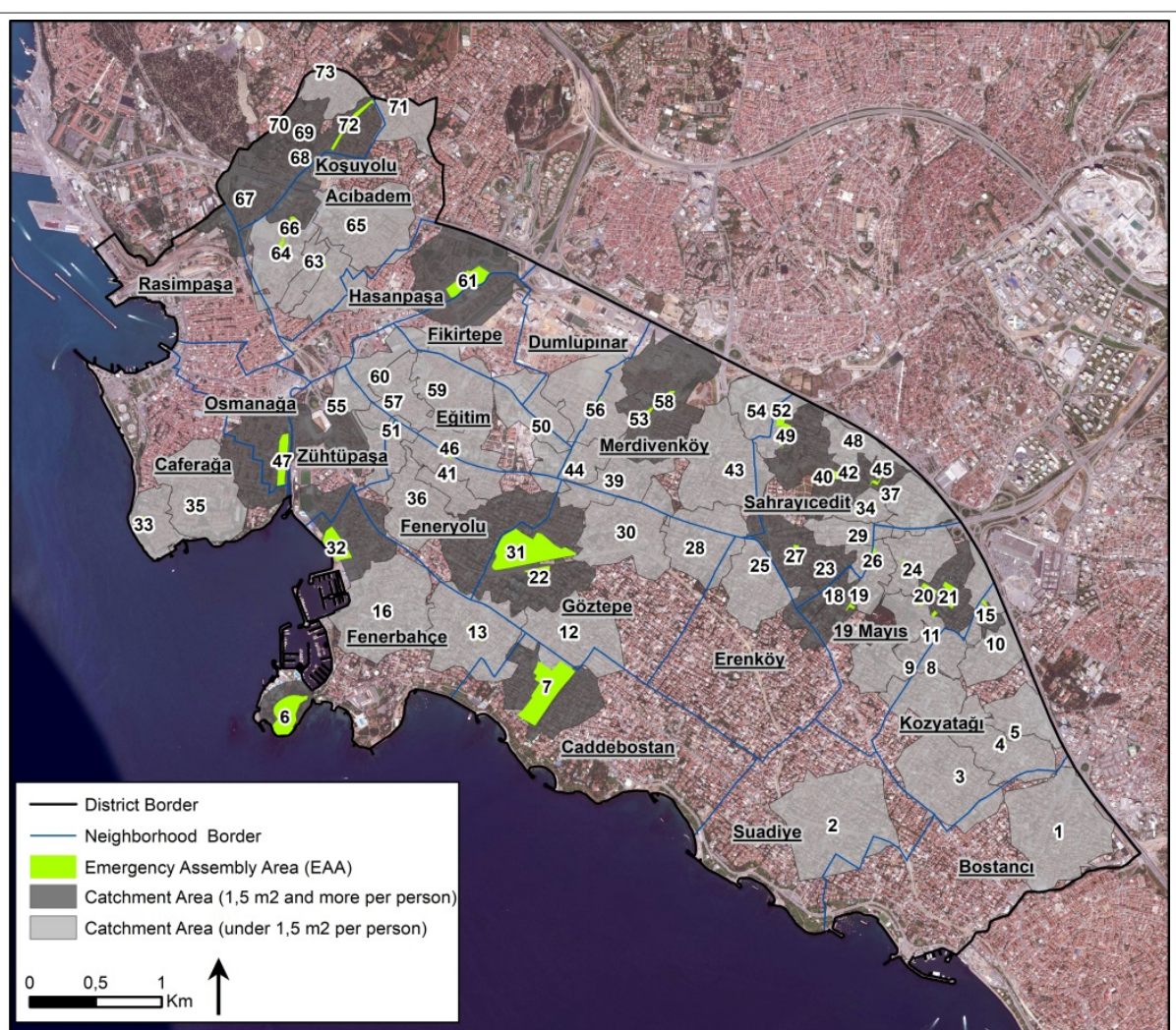

Table 2. Catchment area, population and area per person of each EAA in Kadıköy

\begin{tabular}{|c|c|c|c|c|}
\hline $\begin{array}{l}\text { Code }^{2} \\
5\end{array}$ & Name of the EAA & $\begin{array}{l}\text { Area } \\
\left(\mathrm{m}^{2}\right)\end{array}$ & $\begin{array}{l}\text { Population } \\
\text { of } 500 \mathrm{~m} \\
\text { catchment } \\
\text { area }\end{array}$ & $\begin{array}{l}\text { Area per } \\
\text { person } \\
\left(\mathrm{m}^{2}\right)^{26}\end{array}$ \\
\hline 2 & Suadiye İstasyon Park & 594 & 9.905 & 0,06 \\
\hline 30 & Nadirağa Park & 437 & 6.790 & 0,06 \\
\hline 3 & Firuzan Toprak Park & 765 & 10.212 & 0,07 \\
\hline 65 & Kuruçeşme Park & 552 & 7.295 & 0,08 \\
\hline 1 & Menekșe Park & 848 & 9.561 & 0,09 \\
\hline 35 & Şair Nefi Park & 730 & 7.789 & 0,09 \\
\hline 59 & İnönü İlkokulu Karşısı Park & 568 & 5.899 & 0,10 \\
\hline 46 & Kuyubaşı Park & 453 & 4.471 & 0,10 \\
\hline 28 & Karanfil Sokak Park & 801 & 5.946 & 0,13 \\
\hline 57 & Kemal Sunal Park & 621 & 4.484 & 0,14 \\
\hline 12 & Yeşilçeşme Park & 1055 & 6.148 & 0,17 \\
\hline 43 & Özlem Sokak Park & 1916 & 8.369 & 0,23 \\
\hline 62 & Acıbadem Muhtarlık Park & 1251 & 5.279 & 0,24 \\
\hline 56 & Dumlupınar Park & 1713 & 6.819 & 0,25 \\
\hline 50 & Dumlupınar Muhtarlık Park & 745 & 2.723 & 0,27 \\
\hline 71 & Üçgen Park & 900 & 3.281 & 0,27 \\
\hline 16 & Behice Yazgan Park & 1645 & 5.833 & 0,28 \\
\hline 4 & Barış Park-1 & 2155 & 6.362 & 0,34 \\
\hline 10 & Ilgin Park & 836 & 2.399 & 0,35 \\
\hline 25 & Gardenya Çıkmazı Park & 2024 & 5.229 & 0,39 \\
\hline 36 & 26 Mart Park & 1879 & 4.853 & 0,39 \\
\hline 39 & Leylak Park & 1444 & 3.469 & 0,42 \\
\hline
\end{tabular}

Figure 5. Adequacy analysis of EAAs in Kadıköy

$257,31,47$ and 61 are also
evacuation area
26 The table is sorted by this
column.


An Evaluation of an Integrated Disaster Management and Emergency Assembly Area: The Case of Kadıköy, Istanbul

\begin{tabular}{|c|c|c|c|c|}
\hline 41 & Feneryolu Muhtarlık Park & 659 & 1.472 & 0,45 \\
\hline 63 & Acıbadem Park & 1379 & 2.248 & 0,61 \\
\hline 73 & Mimoza Park & 944 & 1.495 & 0,63 \\
\hline 54 & Eylül Park & 1978 & 3.015 & 0,66 \\
\hline 17 & Sarı Kanarya Park & 1124 & 1.649 & 0,68 \\
\hline 29 & Dostluk Park & 1841 & 2.558 & 0,72 \\
\hline 8 & Ahmet Taner Kıșlalı Park & 2889 & 3.948 & 0,73 \\
\hline 37 & Halk Sokak Park & 2239 & 3.039 & 0,74 \\
\hline 48 & Hilton Otel Yanı Park & 1226 & 1.486 & 0,82 \\
\hline 11 & Kozyatağı Karakol Karşısı Park & 2463 & 2.948 & 0,84 \\
\hline 13 & Çamlık (Ihlamur) Park & 5546 & 5.937 & 0,93 \\
\hline 24 & Ekin Park & 4661 & 4.878 & 0,96 \\
\hline 34 & Mengi Park & 1729 & 1.629 & 1,06 \\
\hline 64 & Sokullu Park & 3714 & 3.355 & 1,11 \\
\hline 14 & Ormen Sitesi Park & 1187 & 1.048 & 1,13 \\
\hline 60 & Dayanışma Park & 2152 & 1.893 & 1,14 \\
\hline 5 & Baıș Park- 2 & 2774 & 2.294 & 1,21 \\
\hline 26 & Akasya Park & 3189 & 2.615 & 1,22 \\
\hline 44 & Ççınar Park & 3310 & 2.696 & 1,23 \\
\hline 33 & Moda Park & 3215 & 2.591 & 1,24 \\
\hline 9 & Zübeyde Hanım Park & 3791 & 2.841 & 1,33 \\
\hline 51 & Sanat Park & 3075 & 2.255 & 1,36 \\
\hline 67 & Öğretmenler Park & 2193 & 1.311 & 1,67 \\
\hline 55 & İntaş 23 Nisan Park & 2657 & 1.574 & 1,69 \\
\hline 27 & Milli Hakimiyet Park & 9668 & 5.362 & 1,80 \\
\hline 53 & Onay Sitesi Park & 6463 & 3.564 & 1,81 \\
\hline 18 & Kuşluk Park & 3589 & 1.763 & 2,04 \\
\hline 42 & Doğa Park & 4469 & 2.169 & 2,06 \\
\hline 58 & Çamlık Park & 8294 & 3.928 & 2,11 \\
\hline 70 & Şeker Park & 1233 & 577 & 2,14 \\
\hline 38 & Arapgirli Park & 1658 & 627 & 2,64 \\
\hline 22 & Demokrasi Park & 10287 & 3.265 & 3,15 \\
\hline 23 & Defne Park & 4359 & 1.279 & 3,41 \\
\hline 19 & 19 Mayıs Park & 7524 & 2.163 & 3,48 \\
\hline 47 & Yoğurtçu Park & 23461 & 6.483 & 3,62 \\
\hline 68 & Manolya Park & 3747 & 1.027 & 3,65 \\
\hline 66 & Jan. Er Cemal Tüfekçioğlu Park & 4668 & 1.253 & 3,73 \\
\hline 49 & Merdivenköy Koru Park & 8232 & 1.985 & 4,15 \\
\hline 72 & Koşuyolu Park & 11736 & 2.563 & 4,58 \\
\hline 40 & 23 Nisan Park & 3902 & 822 & 4,75 \\
\hline 20 & Hürriyet Park & 8995 & 1.869 & 4,81 \\
\hline 61 & Yeni Salı Pazarı & 32294 & 5.579 & 5,79 \\
\hline 52 & Merdivenköy Park & 6036 & 981 & 6,15 \\
\hline 15 & Afet Eğitim ve Biliçlendirme Park & 3106 & 422 & 7,36 \\
\hline 21 & Kriton Curi Park & 13928 & 1.768 & 7,88 \\
\hline 69 & Yaşam Park & 3184 & 404 & 7,88 \\
\hline 45 & Erguvan Park & 3378 & 404 & 8,36 \\
\hline 32 & Kalamış Park & 28535 & 3.129 & 9,12 \\
\hline 31 & Özgürlük Park & 108318 & 10.382 & 10,43 \\
\hline
\end{tabular}




\begin{tabular}{|l|l|l|l|l|}
\hline 7 & Göztepe 60. Yıl Park & 88215 & 3.418 & 25,81 \\
\hline 6 & Fenerbahçe Park & 48446 & 48 & 1009,30 \\
\hline & Total & $\mathbf{5 4 1 5 9 1}$ & $\mathbf{2 6 1 . 1 2 5}$ & $\mathbf{2 , 0 7}$ \\
\hline
\end{tabular}

Table 3. Catchment area, population and area per person of EAAs at the neighborhoods scale in Kadıköy

\begin{tabular}{|c|c|c|c|c|c|}
\hline \multirow[b]{2}{*}{ Neighborhood } & \multirow[b]{2}{*}{ Population } & \multicolumn{2}{|c|}{$\begin{array}{l}\text { Population accessing } \\
\text { EAA in } 500 \mathrm{~m}\end{array}$} & \multicolumn{2}{|c|}{$\begin{array}{l}\text { Population accessing } \\
\text { EAA that provides } \\
1,5 \mathrm{~m}^{2} \text { for each } \\
\text { person within its } 500 \\
\text { m catchment area }\end{array}$} \\
\hline & & Population & $\begin{array}{l}\text { Ratio } \\
\text { to } \\
\text { neighb } \\
\text { orhood } \\
\text { popula } \\
\text { tion } \\
(\%)\end{array}$ & Population & $\begin{array}{l}\text { Ratio } \\
\text { to } \\
\text { neighb } \\
\text { orhood } \\
\text { popula } \\
\text { tion } \\
(\%)^{27}\end{array}$ \\
\hline Bostancl & 31.585 & 11.603 & 37 & 0 & 0,0 \\
\hline Suadiye & 23.690 & 9.340 & 39 & 0 & 0,0 \\
\hline Dumlupınar & 11.718 & 5.537 & 47 & 0 & 0,0 \\
\hline Eğitim & 13.525 & 11.774 & 87 & 0 & 0,0 \\
\hline Rasimpaşa & 13.898 & 104 & 1 & 43 & 0,3 \\
\hline Kozyatağı & 35.230 & 26.182 & 74 & 421 & 1,2 \\
\hline Erenköy & 32.900 & 6.406 & 19 & 797 & 2,4 \\
\hline Acıbadem & 30.041 & 20.728 & 69 & 1.683 & 5,6 \\
\hline Fenerbahçe & 18.166 & 12.969 & 71 & 2.142 & 11,8 \\
\hline Caferağa & 23.379 & 13.286 & 57 & 2.913 & 12,5 \\
\hline Göztepe & 37.013 & 22.280 & 60 & 6.435 & 17,4 \\
\hline Caddebostan & 19.221 & 4.673 & 24 & 3.413 & 17,8 \\
\hline 19 Mayıs & 30.964 & 20.039 & 65 & 6.266 & 20,2 \\
\hline Hasanpaşa & 15.241 & 6.019 & 39 & 3.449 & 22,6 \\
\hline Fikirtepe & 9.069 & 4.189 & 46 & 2.140 & 23,6 \\
\hline Merdivenköy & 33.582 & 28.864 & 86 & 7.928 & 23,6 \\
\hline Feneryolu & 24.327 & 18.538 & 76 & 7.595 & 31,2 \\
\hline Zühtüpaşa & 8.007 & 4.668 & 58 & 2.655 & 33,2 \\
\hline Osmanağa & 8.487 & 3.165 & 37 & 3.170 & 37,3 \\
\hline Sahrayıcedit & 30.901 & 23.882 & 77 & 13.673 & 44,3 \\
\hline Koşuyolu & 7.694 & 6.879 & 89 & 5.396 & 70,1 \\
\hline Total & 458.638 & 261.125 & 57 & 70119 & 15,3 \\
\hline
\end{tabular}

Almost half of the district population has no access to an EAA within 500 $\mathrm{m}$, and so social infrastructure areas should be evaluated as potential secondary assembly areas. Such areas provide shelter, which is important particularly in the aftermath of earthquakes that occur in winter (all EAAs in Kadıköy are used as parks, and so have no covered areas), and such basic infrastructure as electricity and water. It was ascertained in the aftermath of the Elazığ-Malatya earthquake, which occurred in the winter months of 2020, that covered areas are crucial

27 The table is sorted by this column. 
An Evaluation of an Integrated Disaster Management and Emergency Assembly Area: The Case of Kadıköy, Istanbul

for efficient disaster management. Accordingly, $500 \mathrm{~m}$ catchment areas of each of the social infrastructure buildings were determined, along with the population living therein. These assembly areas must not pose a risk, and four of the buildings were excluded from the study, being considered hazardous.

It was determined from a network analysis of road data made in GIS that the catchment areas of the secondary assembly areas cover almost the entire district (95\%), serving 99 percent of the district's population. On the other hand, in the area of the Zühtüpaşa, Fenerbahçe and Caddebostan neighborhoods falling outside the catchment area is higher than for other neighborhoods, with 13 percent of the population of the Zühtüpaşa neighborhood, 8 percent of Fenerbahçe and 3 percent of Caddebostan falling outside of the catchment areas. These areas are also notable for being outside the catchment areas of EAAs.

To be considered adequate, the covered area within secondary assembly areas should provide at least $3.5 \mathrm{~m}^{2}$ as standard for each person within their catchment area (Çוnar et al., 2018). For the district as a whole, this value was determined as $3.9 \mathrm{~m}^{2}$, although in 12 out of the 21 neighborhoods in the district, this value is less than $3.5 \mathrm{~m}^{2}$. In the Fikirtepe, Sahrayıcedit, Merdivenköy and Dumlupınar neighborhoods, the entire population can access secondary assembly areas within 500 $\mathrm{m}$, but these areas are not considered adequate in terms of size. In contrast, this value is 10 times higher than the standard in the Eğitim neighborhood, due to the presence of vast regional social infrastructures in the form of a university and a state hospital (Figure 6; Table 4).

Figure 6. Spatial distribution of secondary assembly areas and their catchment areas in Kadıköy

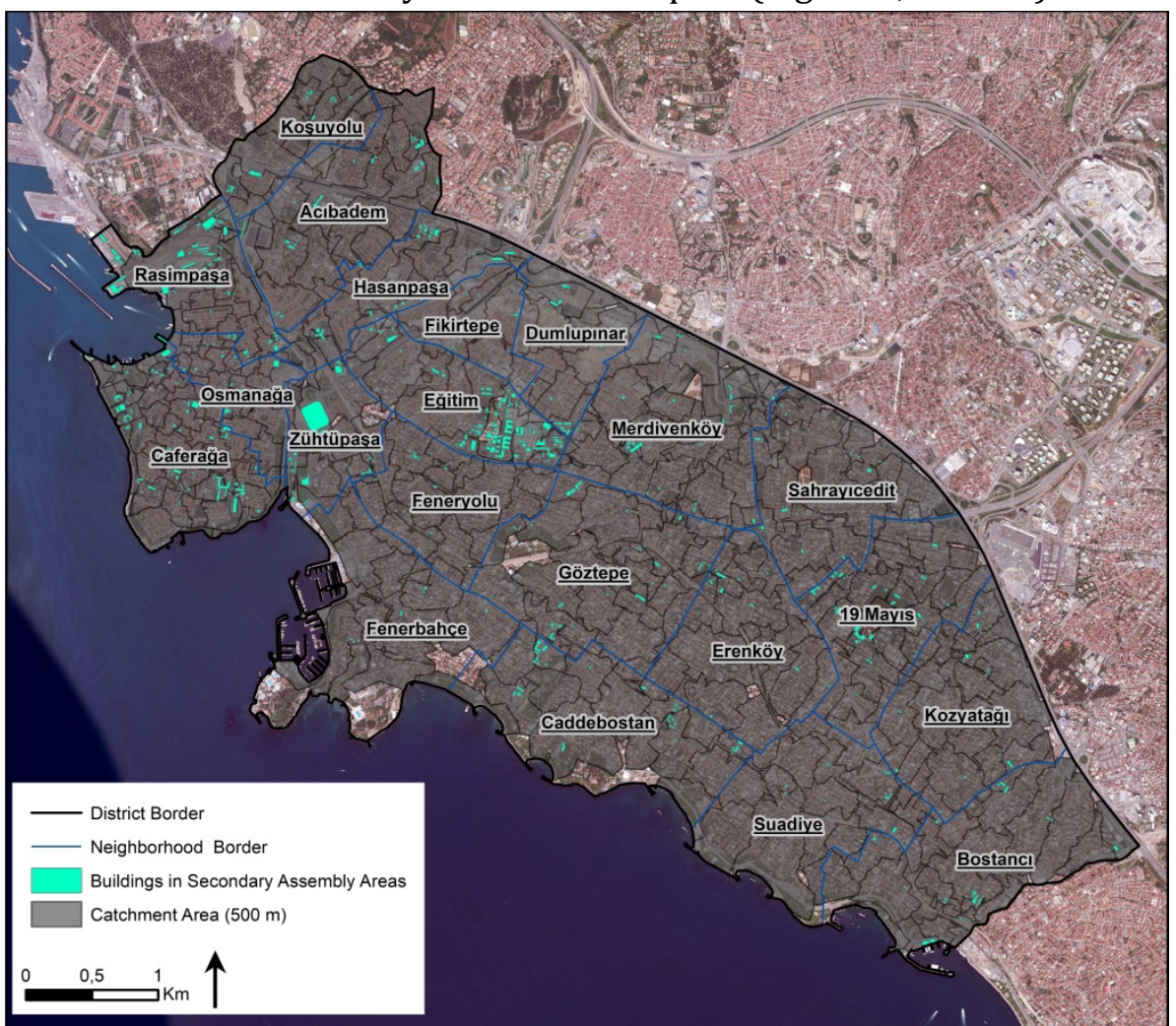


Table 4. Catchment area, population and area per person of secondary assembly areas at the neighborhoods scale in Kadıköy

\begin{tabular}{|c|c|c|c|c|c|}
\hline \multirow{2}{*}{ Neighborhood } & \multirow{2}{*}{ Population } & \multicolumn{2}{|c|}{$\begin{array}{l}\text { Population accessing } \\
\text { secondary assembly area in } \\
500 \mathrm{~m}\end{array}$} & \multirow{2}{*}{$\begin{array}{l}\text { Total } \\
\text { construction } \\
\text { area of } \\
\text { secondary } \\
\text { assembly } \\
\text { areas } \\
\text { buildings } \\
\left(\mathrm{m}^{2}\right)\end{array}$} & \multirow[t]{2}{*}{$\begin{array}{l}\text { Construction } \\
\text { area per } \\
\text { person } \\
\left(\mathrm{m}^{2}\right)^{28}\end{array}$} \\
\hline & & Population & $\begin{array}{l}\text { Ratio to } \\
\text { neighborhood } \\
\text { population } \\
(\%)\end{array}$ & & \\
\hline Fikirtepe & 9.069 & 9.069 & 100,0 & 1.929 & 0,21 \\
\hline Feneryolu & 24.327 & 24.228 & 99,6 & 15.451 & 0,64 \\
\hline Sahrayıcedit & 30.901 & 30.886 & 100,0 & 21.402 & 0,69 \\
\hline Fenerbahçe & 18.166 & 16.681 & 91,8 & 14.184 & 0,85 \\
\hline Suadiye & 23.690 & 23.580 & 99,5 & 23.059 & 0,98 \\
\hline Kozyatağı & 35.230 & 34.989 & 99,3 & 39.040 & 1,12 \\
\hline Erenköy & 32.900 & 32.442 & 98,6 & 36.544 & 1,13 \\
\hline Bostancı & 31.585 & 31.460 & 99,6 & 54.480 & 1,73 \\
\hline Göztepe & 37.013 & 36.705 & 99,2 & 76.023 & 2,07 \\
\hline Merdivenköy & 33.582 & 33.579 & 100,0 & 77.355 & 2,30 \\
\hline Dumlupınar & 11.718 & 11.713 & 100,0 & 30.480 & 2,60 \\
\hline Acıbadem & 30.041 & 30.003 & 99,9 & 89.049 & 2,97 \\
\hline Osmanağa & 8.487 & 8.487 & 100,0 & 31.491 & 3,71 \\
\hline 19 Mayıs & 30.964 & 30.787 & 99,4 & 126.274 & 4,10 \\
\hline Caddebostan & 19.221 & 18.549 & 96,5 & 81.338 & 4,39 \\
\hline Caferağa & 23.379 & 23.372 & 100,0 & 120.017 & 5,14 \\
\hline Hasanpaşa & 15.241 & 15.234 & 100,0 & 86.345 & 5,67 \\
\hline Zühtüpaşa & 8.007 & 6.964 & 87,0 & 64.110 & 9,21 \\
\hline Koşuyolu & 7.694 & 7.694 & 100,0 & 99.474 & 12,93 \\
\hline Rasimpaşa & 13.898 & 13.898 & 100,0 & 184.743 & 13,29 \\
\hline Eğitim & 13.525 & 13.441 & 99,4 & 497.374 & 37,00 \\
\hline Total & 458.638 & 453.761 & 98,9 & 1770162 & 3,90 \\
\hline
\end{tabular}

28 The table is sorted by this column.

\section{CONCLUSION}

Integrated disaster management, and relatedly, EAAs, are subjects of considerable discussion in Turkey, where earthquakes are an inevitable reality. In the urban planning context, the site selection and size, and relatedly, the accessibility and adequacy of EAAs are the crucial topics of analysis. In İstanbul, where the risk of earthquake is high, and where the one-fifth of the country's population resides, such studies of EAAs are of particular importance. In the study, the accessibility and adequacy of EAAs in Kadıköy, as the district of İstanbul with the highest ratio of atrisk buildings, were examined. Besides analyzing accessibility of EAAs as in other studies in the relevant literature, this study tries to contribute literature by adequacy analysis and by using network analysis for accessibility. 
An Evaluation of an Integrated Disaster Management and Emergency Assembly Area: The Case of Kadıköy, Istanbul

Within the scope of the analyses, the prominent results for Kadıköy and suggested solutions to the problems are presented below:

- There are 73 EAAs in Kadıköy.

- Some 57 percent of the district's population resides within $500 \mathrm{~m}$ of an EAA, and so new EAAs should be planned for the rest of the population. The problem should be addressed first in the Rasimpaşa, Erenköy, Caddebostan, Bostancı, Osmanağa, Suadiye and Hasanpaşa neighborhoods, as the most disadvantaged.

- The EAAs coded 33, 35 and 47 in the Caferağa and Osmanağa neighborhoods are accessed via roads that are narrower than 7 $\mathrm{m}$, and so alternative EAAs and access routes should be determined in these neighborhoods.

- Three-quarters of the population have access to EAAs within $500 \mathrm{~m}$ that are inadequate in terms of area. This is a general problem for all neighborhoods in the district. To address this problem, the standard should be followed across the district, and firstly in the Bostancı, Suadiye, Dumlupınar, Eğitim, Rasimpaşa, Kozyatağı, Erenköy and Acıbadem neighborhoods, where less than 10 percent of the population have access to EAAs within $500 \mathrm{~m}$.

- Almost the entire population of the district has access to secondary assembly areas within $500 \mathrm{~m}$, although the area provided in these areas in the Fikirtepe, Feneryolu, Sahrayıcedit, Fenerbahçe, Suadiye, Kozyatağı, Erenköy, Bostancı, Göztepe, Merdivenköy, Dumlupınar and Acıbadem neighborhoods falls short of the standard (minimum $3,5 \mathrm{~m}^{2}$ per person). Accordingly, these areas should be increased.

This study of Kadıköy provides important clues to the efficient disaster management of both other districts in İstanbul and other settlements across Turkey. For efficient integrated disaster management, EAAs should be determined; and the accessibility and adequacy of existing EAAs should be analyzed at settlement scale. When the EAAs have been determined, their accessibility should be analyzed with a network analysis to ascertain the suitability of the access roads. After all, EAAs that are adequate, accessible to all inhabitants and accessed by roads wider than $7 \mathrm{~m}$; and secondary assembly areas that provide shelter and basic infrastructures should be planned.

To realize these suggestions, standards related to size, accessibility and adequacy for both EAAs and secondary assembly areas must be defined in the legal regulations and land-use plans. The Spatial Plan Preparation

${ }^{29}$ https://www.mevzuat.gov. tr/Metin.Aspx?MevzuatKod= 7.5.19788\&Mevzuatlliski $=0 \&$ sourceXmlSearch=PLAN\%20 YAPIMINA\%20A\%C4\%B0T
Regulation ${ }^{29}$ defines a legend for plans of different hierarchies, and the minimum size for social and technical infrastructure areas like schools, health units, etc. As such, to realize the decisions contained within upper scale plans related to integrated disaster management, it is necessary to define a legend for EAAs in local land use and detailed local plans in which the social and technical infrastructures are shown. 
This research analyzed the accessibility and adequacy of EAAs; however, as stated at the literature review, in the wake of a disaster, people should be transferred to the main evacuation area and temporary shelter area from the EAAs. For both evacuation areas and temporary shelter areas, accessibility and adequacy analyses should be carried out in a new research. Additionally, the study has not analyzed the natural and design properties of EAAs, and so in future researches it may be beneficial to analyze both the natural properties of such areas in terms of geology, soil and slope, and the design properties, such as usability, and accessibility for all, especially such disadvantaged groups as the handicapped and the elderly.

\section{CONFLICT OF INTEREST}

No conflict of interest was declared by the authors.

\section{FINANCIAL DISCLOSURE}

The authors declared that this study has received no financial support.

\section{ETHICS COMMITTEE APPROVAL}

Ethics committee approval was not required for this article.

\section{LEGAL PUBLIC/PRIVATE PERMISSIONS}

In this research, the necessary permissions were obtained from the relevant participants during the research.

\section{REFERENCES}

5216 sayılı Büyükşehir Belediyesi Kanunu. (2004). Accessed from: https://www.mevzuat.gov.tr/MevzuatMetin/1.5.5216.pdf

5393 sayll Belediye Kanunu. (2005). Accessed from: https://www.mevzuat.gov.tr/MevzuatMetin/1.5.5393.pdf

6306 sayılı Afet Riski Altındaki Alanların Dönüștürülmesi Hakkında Kanun. (2012). Accessed from: https://www.mevzuat.gov.tr/Metin1.Aspx?MevzuatKod=1.5.6306\&Mev zuatlliski $=0 \&$ sourceXmlSearch $=$ \&Tur $=1 \&$ Tertip $=5 \&$ No $=6306$

Aksoy, Y., Turan, A.Y., \& Atalay, H. (2009). İstanbul Fatih ilçesi yeşil alan yeterliliğinin Marmara depremi öncesi ve sonrası değerleri kullanılarak incelenmesi, Uludağ Üniversitesi Mühendislik-Mimarlık Fakültesi Dergisi, 14 (2), 137-150.

Alt Yapılar için Afet Yönetmeliği. (2007). Accessed from: https://www.mevzuat.gov.tr/Metin.Aspx?MevzuatKod=7.5.11102\&Mev zuatIliski=0\&sourceXmlSearch=alt $\% 20$ yap\%C4\%B1lar

Aman, D., D. (2019). Olası Marmara depreminde toplanma alanları yer seçim kriterlerinin belirlenmesi: İstanbul Bağcllar örneği. Ph.D. Thesis, İstanbul Teknik Üniversitesi, Fen Bilimleri Enstitüsü.

Balamir M. (2007). Afet politikası, risk ve planlama, TMMOB Afet Sempozyumu, 5-7 Aralık İMO Kongre ve Kültür Merkezi, Ankara, Türkiye. 
An Evaluation of an Integrated Disaster Management and Emergency Assembly Area: The Case of Kadıköy, Istanbul

Balamir, M. (2004). Deprem konusunda güncel gelişmeler ve beklentiler, Planlama Dergisi, 1, 15-28.

Balamir, M. (2011). Uluslararası afetler politikasının ana ekseni: kentsel sakınım. 1. Türkiye Deprem Mühendisliği ve Sismoloji Konferansı, 11-14 Ekim ODTÜ, Ankara, Türkiye.

Balamir, M. (2015). Risk yönetimi ve planlama, yeni yaklaşımlar ve Türkiye. Gazi Üniversitesi Kent Söyleşileri. https://www.youtube.com/watch?v=u9svr5T2U14\&t=113s

Balta, M. Ö. (2013). Kentsel risklerin planlama temelinde analizi ve dirençli kent planlama yaklaşımı. Ph.D. Thesis, Gazi Üniversitesi, Fen Bilimleri Enstitüsü.

Buldurur, M. A., \& Kurucu, H. (2015). İstanbul'da Afet Yönetimi ve Acil Ulaşım Yollarının Değerlendirmesi, Planlama Dergisi, 25 (1), 21-31.

Chen, W., Zhai, G., Fan, C., Jin, W., \& Xie, Y. (2017). A planning framework based on system theory and GIS for urban emergency shelter system: A case of Guangzhou, China. Human and Ecological Risk Assessment: An International Journal, 23(3), 441-456. https://doi.org/10.1080/10807039.2016.1185692

Çınar, A. K., Akgün, Y., Maral, H. (2018). Afet sonrası acil toplanma ve geçici barınma alanlarının planlanmasındaki faktörlerin incelenmesi: İzmir-Karşıyaka örneği, Planlama Dergisi, 28(2), 179-200. https://doi.org/10.14744/planlama.2018.07088

Comber, A., Brunsdon, C., Green E. (2008). Using a GIS-Based Network Analysis To Determine Urban Greenspace Accessibility for Different Ethnic and Religious Groups, Landscape and Urban Planning, 86, 103-114.

Dokuzuncu Kalkınma Planı 2007-2013 (2006). Devlet Planlama Teşkilatı. $\quad$ http://www.sbb.gov.tr/wpcontent/uploads/2018/11/Dokuzuncu-Kalk\%C4\%B1nma Plan\%C4\%B1-2007-2013\%E2\%80\%8B.pdf

Erdem, U.; Erdin, E.H., \& Özcan N. S. (2017). Afet ve acil durumlarda erişilebilirlik, 4. Uluslararası Deprem Mühendisliği ve Sismoloji Konferansı, 11-13 Ekim 2017, Anadolu Üniversitesi, Eskişehir, Türkiye.

Erdin, E. H., Aydın, B. S., Partigöç, S. N., Zengin Çelik, H., Palazca, A., Horoz, C.. (2018). Kentiçi Yol Kademelenmesinin Afet Durumunda Toplanma Alanlarının Erişilebilirliğine Etkisi Açısından İrdelenmesi, 2. International Symposium on Natural Hazards and Disaster Management 04-06 Mayıs, Sakarya, Türkiye.

Ergünay, 0.; Gülkan, P., \& Güler, H.H. (2008). Afet yönetimi ile ilgili terimler açıklamalı sözlük. In M, Kadıoğlu, \& E, Özdamar (Eds.). Afet zararlarını azaltmanın temel ilkeleri, (1 ${ }^{\text {st }}$ ed., pp. 301-353). Ankara, JICA Türkiye Ofisi Yayınları.

Güler, H.H. (2008). Zarar azaltma ve şehir planlama. In M, Kadıoğlu, \& E, Özdamar (Eds.). Afet zararlarını azaltmanın temel ilkeleri, (1 ${ }^{\text {st }}$ ed., pp. 35-57). Ankara, JICA Türkiye Ofisi Yayınları. 
İDMP (2003). İstanbul için deprem master planı. Planlama ve İmar dairesi Zemin ve Deprem İnceleme Müdürlüğü. http://www.ibb.gov.tr/trTR/SubSites/DepremSite/Documents/\%C4\% B0DMP_TUR.pdf İstanbul Kentsel Dönüşüm Master Planı Analiz verileri, 2016).

JICA (Japon Uluslararası İşbirliği Ajansı) \& İBB (İstanbul Büyükşehir Belediyesi). (2002). Türkiye Cumhuriyeti İstanbul ili sismik mikrobölgeleme dâhil afet önleme/azaltma temel planı çalışması son rapor. http://www.ibb.gov.tr/trTR/SubSites/DepremSite/PublishingImages/ JICA-TUR.pdf

Kadıoğlu, M. (2008). Modern, bütünleşik afet yönetimin temel ilkeler. In M, Kadığlu, \& E, Özdamar (Eds.). Afet zararlarını azaltmanın temel ilkeleri, (1st ed., pp. 1-34). Ankara, JICA Türkiye Ofisi Yayınları.

Kadığlu, M. (2011). Afet yönetimi: beklenilmeyeni beklemek ve en kötüsünü yönetmek. İstanbul, Marmara Belediyeler Birliği Yayını.

Kar, B., \& Hodgson, M. E. (2008). A GIS-Based Model to Determine Site Suitability of Emergency Evacuation Shelters. Transactions in GIS, 12(2), 227-248. https://doi.org/10.1111/j.1467-9671.2008.01097.x

KENTGES (Bütünleşik Kentsel Gelişme Stratejisi ve Eylem Planı) 20102023 (2010). T.C. Çevre ve Şehircilik Bakanlığı. https://webdosya.csb.gov.tr/db/kentges/editordosya/kentges_tr.pdf

Kundak, S. (2014). Kentsel risklerin azaltılması. İstanbul: İstanbul il afet ve acil durum müdürlüğü (İstanbul AFAD) ve İstanbul Proje Koordinasyon Birimi (İPKB), ISMEP Yayınları. https://www.ipkb.gov.tr/wpcontent/uploads/2018/10/ISMEP8_KentselRisklerinAzaltC4B1lmasC4B 1.pdf

Li, A. C. Y., Nozick, L., Xu, N., \& Davidson, R. (2012). Shelter location and transportation planning under hurricane conditions. Transportation Research Part E: Logistics and Transportation Review, 48(4), 715-729. https://doi.org/10.1016/j.tre.2011.12.004

Mekânsal Planlar Yapım Yönetmeliği. (2014). Accessed from: https://www.mevzuat.gov.tr/Metin.Aspx?MevzuatKod=7.5.19788\&Mev zuatIliski=0\&sourceXmlSearch=PLAN\%20YAPIMINA\%20A\%C4\%B0T\% 20ESASLARA\%20DA\%C4\%B0R\%20Y\%C3\%96NET

Okay N. (2018). Afete dirençli kentlerde risk azaltma, Şehir ve Toplum, 10, 117-127.

Okay, N. (2019). Afet risk yönetiminde yaklaşımlar, Mimar ve Mühendisler Grubu, 109, 54-57.

On Birinci Kalkınma Planı 2019- 2023 (2019). T.C. Strateji ve Bütçe Başkanlığı. http://www.sbb.gov.tr/wp-content/uploads/2019/07/OnBirinci-Kalkinma-Plani.pdf

Onuncu Kalkınma Planı 2014- 2018 (2013). T.C. Kalkınma Bakanlığı. http://www.sbb.gov.tr/wp-content/uploads/2018/11/OnuncuKalk\%C4\%B1nma-Plan\%C4\%B1-2014-2018.pdf

Planlı Alanlar İmar Yönetmeliği. (2017). Accessed from: https://www.mevzuat.gov.tr/Metin.Aspx?MevzuatKod=7.5.23722\&Mev zuatlliski=0\&sourceXmlSearch=Planl\%C4\%B1 
An Evaluation of an Integrated Disaster Management and Emergency Assembly Area: The Case of Kadıköy, Istanbul

T.C. İçişleri Bakanlığı, Afet ve Acil Durum Yönetimi Başkanlığı. (2019). Toplanma Alanını Öğren ki Canın Sağ Olsun-Basın Duyurusu. Basın ve Halkla İlişkiler Müşavirliği. https://www.afad.gov.tr/toplanma-alaniniogren-ki-canin-sag-olsun

TAMP (Türkiye Afet Müdahale Planı) (2013). T.C. İçişleri Bakanlığı Afet ve Acil Durum Yönetimi Başkanlığı. https://www.afad.gov.tr/kurumlar/afad.gov.tr/2419/files/Afet_Mud_Pl _ResmiG_20122013.pdf

Tansley, G.; Schuurman, N.; Amram, O., \& Yanchar, N. (2015). Spatial access to emergency services in lowand middle-income countries: A GISbased analysis, PLOS ONE, 10 (11), 1-12.

Tarabanis, K., \& Tsionis, I. (1999). Using network analysis for emergency planning in case of an earthquake. Transactions in GIS, 3(2), 187-197. https://doi.org/10.1111/1467-9671.00015

Tezer, A. (2001). Afet yönetimi ilkeleri. İstanbul, İTÜ Afet Yönetim Merkezi Yayınları, İTÜ press.

Tezer, A., \& Türkoğlu, H. (2008). Zarar azaltmanın temel ilkeleri. In M, Kadıoğlu, \& E, Özdamar (Eds.). Afet zararlarını azaltmanın temel ilkeleri, (1'st ed., pp. 59-71). Ankara, JICA Türkiye Ofisi Yayınları.

Tezer, A., Okay, N., \& Terzi F. (2015). Gaziosmanpaşa İlçesi'nde güvenli yerleşim için mekânsal risk yönetim kapasitesinin geliştirilmesi proje raporu. İstanbul, Gaziosmanpaşa Belediyesi.

Tokyo Metropolitan Goverment TMG, (2015). Disaster Preparedness Tokyo. TMG Tokyo Metropolitan Goverment. http://www.metro.tokyo.jp/ENGLISH/GUIDE/BOSAI/index.htm

TÜİK (2019). Adrese Dayalı Nüfus Kayıt Sistemi. https://biruni.tuik.gov.tr/medas/?kn=95\&locale=tr

UDSEP (Ulusal Deprem Stratejisi ve Eylem Planı) 2012-2023 (2011). Başbakanlık Afet ve Acil Durum Yönetimi Başkanlığı. https://deprem.afad.gov.tr/downloadDocument?id=1643

Unal, M., \& Uslu, C. (2016). Gis-based accessibility analysıs of urban emergency shelters: the case of Adana city, 3. International GeoAdvances Workshop, 16-17 Ekim, İstanbul, Turkiye.

Url-1<https://www.cnnturk.com/video/turkiye/toplanma-alanlarinasil-olmali>, access date: 22.01.2020.

Url-2<https://webgis.kadikoy.bel.tr/keos/>, access date: 25.01.2020

Url-

$3<$ https://www.mevzuat.gov.tr/Metin.Aspx?MevzuatKod=7.5.19788\&M evzuatlliski=0\&sourceXmlSearch=PLAN\%20YAPIMINA\%20A\%C4\%B0T $\% 20$ ESASLARA $\% 20 \mathrm{DA} \% \mathrm{C} 4 \% \mathrm{~B} 0 \mathrm{R} \% 20 \mathrm{Y} \% \mathrm{C} 3 \% 96 \mathrm{NET} \geq$, access date: 20.01.2020

Url-4 https://www.metro.tokyo.lg.jp/english/guide/bosai/index.html., access date: 10.10 .2020

Wex, F., Schryen, G., Feuerriegel, S., \& Neumann, D. (2014). Emergency response in natural disaster management: Allocation and scheduling of 
rescue units. European Journal of Operational Research, 235(3), 697708. https://doi.org/10.1016/j.ejor.2013.10.029

Ye, M.; Wang, J.; Huang, J.; Xu, S., \& Chen, Z. (2012). Methodology and its application for community-scale evacuation planning against earthquake disaster, Nat Hazards, 61, 881-892.

Zengin Çelik, H., Erdin, H. E., Sılaydın Aydın, B., \& Partigöç, N. S. (2019). Farklı kentsel dokuların toplanma alanı olanağı açısından değerlendirilmesi: İzmir-Narlıdere ilçesi örneği. Çukurova Araştırmaları, 5 (2), 276-293. https://doi.org/10.18560/cukurova.1138

Zengin Çelik, H., Özcan, N. S., \& Erdin, E. H. (2017). Afet ve acil durumlarda halkın toplanma alanlarının kullanılabilirliğini belirleyen kriterler, 4. Uluslararası Deprem Mühendisliği ve Sismoloji Konferansı, 11-13 Ekim 2017, Anadolu Üniversitesi, Eskişehir, Türkiye.

\section{Resume}

Dr. Yasin Bektas is an Assistant Professor in the Faculty of Architecture, Department of City and Regional Planning, at Erciyes University, Kayseri/Turkey. He received Ph.D. (2017) from Yildiz Technical University, in urban planning program. Earned his master's degree (MSc) (2011) in urban planning program at Erciyes University and bachelor's degree (2009) in Department of City and Regional Planning from same university. His general research interests are social housing, social interaction, disasters risk, urban regeneration and urban resilience.

Dr. Adem Sakarya is research assistant in the Faculty of Architecture, Department of City and Regional Planning, at Yildiz Technical University, Istanbul/Turkey. He graduated from Istanbul Technical University, Department of City and Regional Planning in 2010 and he earned his master's degree (MSc) in regional planning program at same university in 2013. He finished his Ph.D. (2019) at urban planning program in Yildiz Technical University. The area of interest focuses on urban planning, regional planning, accessibility, geographical information system. 